\title{
CLINICAL PROFILE OF SICKLE CELL ANAEMIA IN ADOLESCENT AND ADULT PATIENTS IN CENTRAL INDIA
}

\author{
Bharatsing Deorao Rathod, Sunil Dhanaraj Bhaisare ${ }^{2}$
}

${ }^{1}$ Associate Professor, Department of General Medicine, Grant Government Medical College and Sir JJ Hospital, Mumbai.

${ }^{2}$ Associate Professor, Department of General Medicine, Grant Government Medical College and Sir JJ Hospital, Mumbai.

\section{ABSTRACT}

\section{BACKGROUND}

Sickle cell anaemia is a commonly encountered inherited haematological disorder in Central India. Despite the unicity of the genetic mutation that is responsible, clinical presentation of the sickle cell haemoglobinopathy was found to be different according to regions and patients.

Aims and Objectives- To study the clinical profile of sickle cell anaemia with particular reference to vaso-occlusive crisis and to estimate the quantity of foetal haemoglobin (HbF) with High Performance Liquid Chromatography (HPLC).

\section{MATERIALS AND METHODS}

In this descriptive study, 120 cases of sickle cell anaemia (SS pattern), having age 12 years and above, attending medicine and/or sickle cell OPD or admitted in medicine indoor wards were included. Cases were subjected to detailed history, clinical examination and laboratory investigations including HPLC. Various parameters (clinical and laboratory) and quantity of HbF were studied.

\section{RESULTS}

Maximum cases, 70 out of 120 (58.3\%) were in 13 - 19 age group range. Mean age of onset of symptom was 8.04 years. Vasoocclusive crisis (VOC) was the most common manifestation followed by severe anaemia, while leg ulcers and stroke were rare presentations. The frequency of VOC varied widely among cases with range of $0.3-3$ episodes per year, the average frequency being 0.6 episodes per case per year. The most common site of pain in VOC were limbs (68.7\%), hands (62.5\%), knees (59.3\%), abdomen (31.2\%) and chest (25\%). Fever was the most common precipitating factor for VOC (31.2\%). The mean HbF level was $21.9 \%$.

\section{CONCLUSION}

Vaso-occlusive crisis was observed to be the most common presentation in sickle cell anaemia. Sickle cell anaemia patients had high levels of foetal haemoglobin from this region.

\section{KEYWORDS}

Sickle Cell Anaemia, HbF.

HOW TO CITE THIS ARTICLE: Rathod BD, Bhaisare SD. Clinical profile of sickle cell anaemia in adolescent and adult patients in Central India. J. Evolution Med. Dent. Sci. 2017;6(47):3638-3641, DOI: 10.14260/Jemds/2017/784

\begin{abstract}
BACKGROUND
Sickle cell anaemia alone is the most common heritable haematologic disease affecting humans. The prevalence of sickle cell anaemia in Central India is high in certain localities of Vidharbha region of Maharashtra. ${ }^{1}$ Most of the patients with sickle cell anaemia suffer from haemolytic anaemia. In situ sickling of RBCs in connective and musculoskeletal structures produces painful ischaemia manifested by acute pain and tenderness, fever, tachycardia and anxiety. These recurrent episodes, called vaso-occlusive or painful crisis (VOC), are the most common clinical manifestations. ${ }^{2}$
\end{abstract}

Financial or Other, Competing Interest: None

Submission 10-05-2017, Peer Review 04-06-2017,

Acceptance 09-06-2017, Published 12-06-2017.

Corresponding Author:

Bharatsing Deorao Rathod,

\#25, Old Subhedar Layout,

Sharada Chowk,

Near Aadarsh Vidhya Mandir,

Nagpur-440024,

Maharashtra.

E-mail: rathodbharatsing@rediffmail.com

DOI: $10.14260 /$ jemds $/ 2017 / 784$
Despite the unicity of the genetic mutation that is responsible, clinical presentation of the sickle cell anaemia was found to be different according to regions and patients. Phenotypic heterogeneity of patients with sickle cell anaemia were linked to the difference between haplotypes of beta globin gene. Five haplotypes were identified in the worldBenin, Senegal, Bantu, Cameroon and Arabian-Indian. Senegal and Arabian-Indian haplotype are associated with moderate form of sickle cell anaemia. ${ }^{3}$ Several biological and environmental factors are presumed to account for the morbidity pattern in patients with sickle cell anaemia e.g. foetal haemoglobin is one of the biological factors thought to decrease morbidity in these patients. Haemoglobin F level has been a useful criterion in predicting the clinical severity of sickle cell anaemia. Many studies had shown the relationship between haemoglobin $\mathrm{F}$ value and clinical severity in sickle cell anaemia patients. ${ }^{4,5,6}$

In this study, we had studied clinical profile of sickle cell anaemia patients including frequency of vaso-occlusive crisis, age of onset of symptom, antecedent blood transfusion, jaundice, gallstones, splenic size, acute chest syndrome, degree of anaemia, avascular necrosis, leg ulcer and $\mathrm{HbF}$ level. 
There are some studies on the epidemiological patterns of sickle cell anaemia in various endemic belts and among specific communities in India. Since little recent published data is available on this topic from Central India, we undertook the present study.

\section{MATERIALS AND METHODS}

A descriptive study was conducted at a tertiary care teaching hospital in Central India. Study participants comprised of cases of sickle cell anaemia, attending General Medicine OPD, sickle cell OPD and Indoor wards of Department of Medicine, with age $>12$ years, irrespective of their gender, caste and ethnic background. The present study was carried out from September 2006 to August 2008. Cases who had received blood transfusion within three months prior to the day of inclusion and cases who were and/or are on hydroxyurea therapy were excluded. Total number of sickle cell anaemia cases studied were 120. After screening consecutive cases of sickle cell anaemia, as per above criteria, and after detailed history and complete clinical examination, $3 \mathrm{~mL}$ of venous blood was withdrawn, mixed with EDTA and sent to pathology laboratory for HPLC. Other laboratory and radiological investigations were also done. Participants not giving valid written consent were excluded from this study. The study was approved by institutional ethics committee.

Statistical analysis was performed using SPSS software version 18 (SPSS Inc. Released 2009. PASW Statistics for Windows, Version 18.0). We performed a descriptive analysis with quantitative variables expressed as mean \pm standard deviations and qualitative variables as number and percentage.

\section{RESULTS}

Age range was from 13 to 50 years with majority of cases belonging to 13 - 19 years age group (58.33\%). 66 (55\%) cases were from Mahar community, 22 (18.33\%) cases were from Kunbi community, 08 (06.67\%) cases from Muslim community. Table no. 1 shows various presentations of cases in this study. The mean age of onset of first symptom was 8.04 years. Majority of cases i.e. 60 (50\%) became symptomatic between 5-10 years age group. (Table no. 2). Average frequency of VOC was 0.6 per case per year but varied from 0 to 3 episodes per case per year. (Table no. 3 ). Most common site for pain in VOC were limbs (68.75\%), followed by hands (62.50\%), knees (59.37\%), abdomen $(31.25 \%)$, chest $(25 \%)$ and back $(9.37 \%)$. Table no. 4 shows the precipitating factors for VOC. 85 cases $(70.83 \%)$ had jaundice, 36 cases (30\%) had gallstones. Mean BMI was 16.82 $\pm 2.38 \mathrm{Kg} / \mathrm{m}^{2}$ (Range - 12.14-21.50). Mean haemoglobin level was $6.75 \pm 2.99 \mathrm{~g} / \mathrm{dL}$ (Range - 3.33-10.17). 42 cases (35\%) had haemoglobin less than $6 \mathrm{~g} / \mathrm{dL} .74$ cases $(61.67 \%)$ had history of antecedent blood transfusion. 41 cases $(31.16 \%)$ had autosplenectomy while 32 cases (26.67\%) had splenomegaly. None of the cases had history of dactylitis or priapism. Mean $\mathrm{HbF}$ level was $21.97 \pm 7.27 \%$, slightly higher in females $(22.19 \pm 7.15)$ as compared to males $(21.68 \pm$ 7.48).

\begin{tabular}{|c|c|}
\hline Presentation & Cases (n=120) \\
\hline VOC (joint pains, etc.) & $64(53.33 \%)$ \\
\hline Severe Anaemia (generalised weakness) & $42(35 \%)$ \\
\hline AVN (head of femur) & $16(13.33 \%)$ \\
\hline Infections & $20(16.67 \%)$ \\
\hline Acute chest syndrome (ACS) & $08(06.67 \%)$ \\
\hline Leg ulcer & $02(01.67 \%)$ \\
\hline Stroke & $01(00.83 \%)$ \\
\hline Asymptomatic & $46(38.33 \%)$ \\
\hline Table 1. Presentation of Cases in Present Study \\
\hline
\end{tabular}

*The total percentage exceeds $100 \%$ because many cases had more than one symptom. VOC- vaso-occlusive crisis; AVN- avascular necrosis; ACS- acute chest syndrome.

\begin{tabular}{|c|c|}
\hline Age of Onset of First Symptom & Cases (n =120) \\
\hline $\begin{array}{c}\text { Less than 5 years } \\
\text { (Range - 3.5-4.9 years) }\end{array}$ & $32(26.66 \%)$ \\
\hline $\begin{array}{c}\text { Between 5 to 10 years } \\
\text { (Range - 5-10 years) }\end{array}$ & $60(50 \%)$ \\
\hline $\begin{array}{c}\text { After 10 years } \\
\text { (Range - 10.5- 26 years) }\end{array}$ & $28(23.33 \%)$ \\
\hline Total & $120(100 \%)$ \\
\hline Table 2. Age of Onset of First Symptom
\end{tabular}

\begin{tabular}{|c|c|}
\hline $\begin{array}{c}\text { Frequency of VOC (Average Number } \\
\text { of Episodes Per Year) }\end{array}$ & $\begin{array}{c}\text { Number of Cases } \\
(\mathbf{n = 1 2 0})\end{array}$ \\
\hline No VOC & $10(08.33 \%)$ \\
\hline 1VOC (Range 0.3-1) & $56(46.67 \%)$ \\
\hline 1 VOC (Range 1.2-3) & $54(45 \%)$ \\
\hline Total & $120(100 \%)$ \\
\hline $\begin{array}{c}\text { Table 3. Frequency of Vaso-occlusive Crisis } \\
\text { (Average Number of Episodes per Year) }\end{array}$ \\
\hline
\end{tabular}

\begin{tabular}{|c|c|}
\hline Precipitating Factor of VOC & Number of Patients (n=64) \\
\hline Fever & $20(31.25 \%)$ \\
\hline Exposure to cold & $16(25 \%)$ \\
\hline $\begin{array}{c}\text { Exhaustion and severe } \\
\text { physical activity }\end{array}$ & $14(21.87 \%)$ \\
\hline Dehydration & $04(06.25 \%)$ \\
\hline Unidentified & $10(15.62 \%)$ \\
\hline Total & $\mathbf{6 4}(100 \%)$ \\
\hline $\begin{array}{c}\text { Table 4. Precipitating Factors of } \\
\text { Vaso-occlusive Crisis in Present Study }\end{array}$ \\
\hline
\end{tabular}

\section{Clinical Photographs}

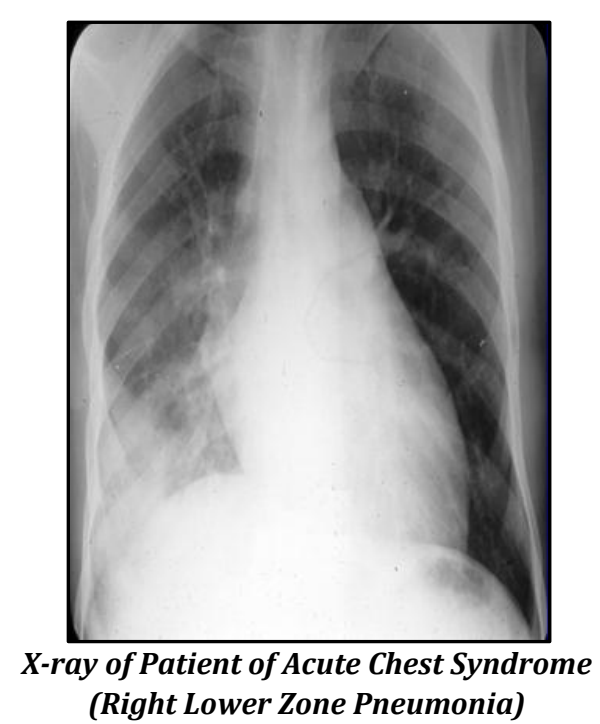




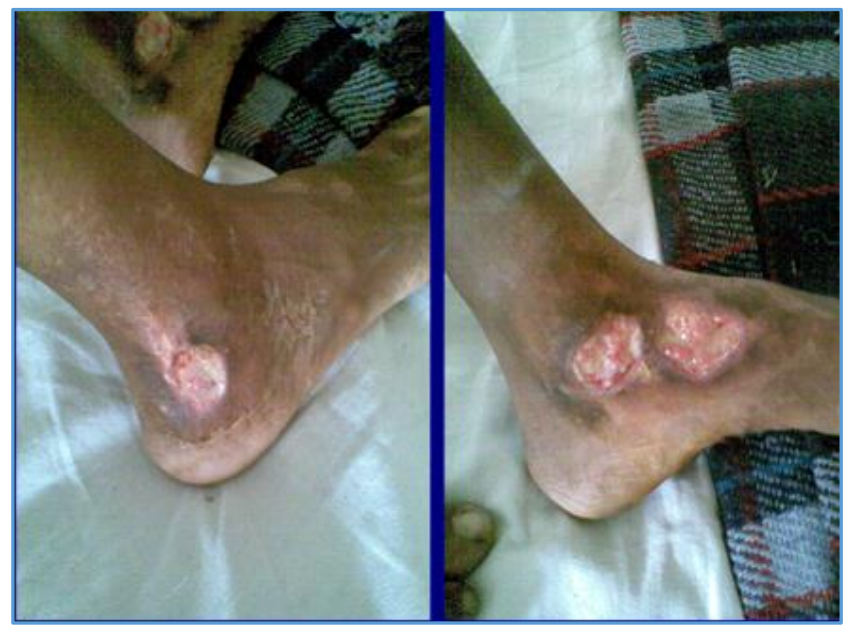

Chronic Leg Ulcers in Patient with Sickle Cell Anaemia

\section{DISCUSSION}

Sickle cell anaemia is an important public health problem in Central India. Maximum cases are from scheduled caste and belonging to poor socioeconomic strata. It is common in younger age group and is an important cause of morbidity and mortality in early childhood. There is lack of knowledge regarding its genetic basis and various phenotypes among masses. We can, to some extent, decrease the burden of disease in society by genetic counselling and by creating awareness among general population.

In the present study, male population outnumbered female population with male to female ratio of 1.22:1. The higher number of males can be explained by the sex ratio in our region. ${ }^{7,8}$ Shrikhande AV et $\mathrm{al}^{9}$ also reported similar male to female ratio in sickle cell anaemia patients in this region. In present study mean $\mathrm{HbF}$ was $21.91 \pm 7.27 \%$, being slightly higher in females as compared to males. These values are consistent with the findings observed by Shrikande AV et al ${ }^{9}$ $\mathrm{HbF}$ production was genetically determined and Arab-Indian haplotype is associated with higher HbF levels as compared to Cameroon haplotype. This explains the low value of $\mathrm{HbF}$ in Nigerian population by Kotila TR et al. ${ }^{4} \mathrm{~S}$ Diop et al $^{10}$ reported mean age of onset of first symptom in sickle cell anaemia was 9.8 years in Senegal. Orah SP et $\mathrm{al}^{11}$ found that it was 1.6 years in USA. Mean age of onset was 8.04 years in present study. High $\mathrm{HbF}$ level in RBCs protects them from sickling, the phenomenon responsible for clinical manifestation of the haemoglobinopathy. So manifestations of sickle cell anaemia are delayed due to high $\mathrm{HbF}$ levels. ${ }^{12} \mathrm{~S}$ Diop et $\mathrm{al}^{10}$ and Powars DR et $\mathrm{al}^{5}$ observed VOC as the most common manifestation in sickle cell anaemia patients. This finding was constant in present study. VOC frequency vary from person to person depending on various environmental and genetic factors. Some cases with very low frequency of VOC or no VOC are commonly seen in regions associated with Senegal and Arab-Indian haplotype. Enosolease ME et $\mathrm{al}^{6}$ observed that VOC was more common at lower levels of foetal haemoglobin particularly when lower than $12 \%(\mathrm{p}=0.01)$. Similar observation was made by Al-Hagger $M$ et al ${ }^{13}$ in Egyptian sickle cell anaemia patients. But Powars DR et $\mathrm{al}^{5}$ observed no significant co-relation between frequency of VOC and $\mathrm{HbF}$ levels in their study. It could be explained on the basis that study carried out by Powars DR et $\mathrm{al}^{5}$ in USA had very low $\mathrm{HbF}$ levels and so overall protective effect was small.
There may be some threshold level of $\mathrm{HbF}$ needed above which it ameliorates the severity of sickle cell anaemia. ${ }^{14}$

Incidence of acute chest syndrome, leg ulcers, stroke were significantly lower in present study and in study done by $\mathrm{S}$ Diop et al ${ }^{10}$ in Senegal as compared to the observations made by Powars DR et $\mathrm{al}^{5}$ in USA. Dactylitis and priapism were reported to occur in significant number of cases of sickle cell anaemia in America and Jamaica, but cases of dactylitis or priapism were not seen in our study. ${ }^{15,16}$

Powars DR et $\mathrm{al}^{5}$ in their prospective study observed that incidence of AVN was 15\%. In present study, 16 cases (13.33\%) had AVN. Patients with higher HbF levels are protected from arterial vasculopathy and subsequent major organ destruction as compared to patients having low $\mathrm{HbF}$ level. These patients are healthier but in time will show the deleterious effect of $\mathrm{HbS}$ as AVN and retinopathy usually begin after age 30 and sickle nephropathy after age of 40 years. ${ }^{17}$

Kotila TR et $\mathrm{al}^{4}$ in their study observed that patients with higher HbF levels are more likely to retain their spleen longer than their counterpart with lower values. Though Western researchers reported autosplenectomy as a frequent phenomenon in sickle cell anaemia patients, persistence of spleen is more commonly encountered in Indian scenario. Subhedar et al ${ }^{18}$ reported splenomegaly in $58.66 \%$ of cases. Rita Sarkar et al ${ }^{19}$ found that $65 \%$ sickle cell anaemia patients had splenomegaly. In present study, 32 cases $(26.67 \%)$ had splenomegaly. In sickle cell anaemia patients, recurrent infarction in the spleen leads to destruction of the organ i.e. autosplenectomy and functional hyposplenism. If episodes of infarction are minimal and there is chronic haemolysis, splenomegaly can be present in such patients.

Variations in the severity of sickle cell disease between individuals usually defy explanation. Some factors have been identified that ameliorate the severity of the condition, however. The most important of these is a high level of $\mathrm{HbF}$ in the erythrocytes. ${ }^{11}$ The first insight into the role of foetal haemoglobin in the clinical manifestations of sickle cell anaemia was made by a paediatrician, Janet Watson. ${ }^{20}$ Patients with sickle cell disease who also have hereditary persistence of foetal haemoglobin (HPFH) often have few if any symptoms. ${ }^{21}$ In these individuals, $\mathrm{HbF}$ usually comprises greater than $20 \%$ of the haemoglobin in the erythrocytes. $\mathrm{HbF}$ disrupts the polymerisation of deoxy-Hb-S. Since polymerisation of deoxy-Hb-S is the signal event in the pathogenesis of sickle cell anaemia, $\mathrm{HbF}$ effectively prevents disease manifestation. The distribution of $\mathrm{HbF}$ among RBCs is also important. In hereditary persistence of foetal haemoglobin (HPFH), HbF exists at high levels in all red cells so all red cells are equally protected from sickling. In the absence of HPFH, patients with high levels of $\mathrm{HbF}$ have a heterogeneous distribution of foetal haemoglobin between cells and patient would experience many of the manifestations of sickle cell disease.

The Arab-India and the Senegal haplotypes are linked to determinants of high levels of persisting $\mathrm{HbF}$ (mean $20 \%$ and $12 \%$ respectively) in subjects with sickle cell anaemia. The Benin and Bantu haplotypes are associated with lower levels of $\mathrm{HbF}$ (mean 8\%), but for reasons which are not yet understood, disease is more severe with the Bantu than Benin haplotype. ${ }^{3}$ Sickle cell anaemia with high levels of $\mathrm{HbF}$, linked to Arab-India and Senegal haplotype is associated with a 
more normal body build, more subcutaneous fat, less dactylitis, less acute chest pain, less splenic atrophy and less major organ failure in adult life. Haemoglobin concentration are higher, RBC survival is longer, there are few sickle cells and reticulocyte and platelet counts are lower in these patients.

We have some limitations of our study. The study population in present study was small. Large number of patients of sickle cell disease are needed to confirm results of the present study. It was a cross sectional analytical study and there was no followup of cases of sickle cell anaemia. Prospective study is necessary to calculate the various incidence rates and for proper evaluation of clinical profile.

\section{CONCLUSION}

Vaso-occlusive crisis is observed to be the most common presentation in sickle cell anaemia. Stroke and leg ulcers are uncommon manifestations in this region. $\mathrm{HbF}$ levels are higher in sickle cell anaemia patients in this region.

\section{ACKNOWLEDGEMENTS}

Dr. S. D. Suryawanshi, Ex-Professor and Head of the Department and Dr. P.P. Joshi, Prof. and Head, Department of Medicine, Indira Gandhi Government Medical College, Nagpur, Maharashtra.

\section{REFERENCES}

[1] Shukla RN, Parande AS. Occurrence of sickle cell anemia and cases of sickle cell trait in Nagpur. Indian Journal of Medical Science 1956;10:892.

[2] Diggs LW. Sickle cell crises. Amer J Clin Path 1965;44(1):1-19.

[3] Fleming AF, de Silva PS. Hematological diseases in the tropics. In: Cook GC, Zumla A. eds. Manson's tropical diseases. $21^{\text {st }}$ edn. Philadelphia: WB Saunders 2003;13:200-01.

[4] Kotila TR, Fawole OL, Shokunbi WA, et al. Hemoglobin $\mathrm{F}$ and clinical severity of sickle cell anemia among Nigerian adults. African J Med Med Sci 2000;29(34):229-31.

[5] Powars DR, Weiss JN, Chan LS, et al. Is there a threshold level of fetal hemoglobin that ameliorates morbidity in sickle cell anemia? Blood 1984;63(4):921-6.

[6] Enosolease ME, Ejele OA, Awodu OA, et al. The influence of fetal hemoglobin on the frequency of vasoocclusive crisis in sickle cell anemia patients. Niger Postgrad Med J 2005;12(2):102-5.

[7] Sex ratio in Maharashtra stands at 922 for 1000 men: study. UNI Sept 14, 2007. 8. Nagpur district information, Nagpur. Nic.in/divisional commissioner/ Dist_info/nag.html.
[8] Shrikhande AV, Dani AA, Tijare JR, et al. Hematological profile of sickle cell disease in Central India. Indian J Hemat Blood Transf 2007;23(3-4):92-8.

[9] Diop S, Thiam D, Cisse M, et al. New results in clinical severity of homozygous sickle cell anemia in Dakar, Senegal. Sevice d'Hematologie et d'Immunologie, CNTS, Dakar-Fann Senegal. Hematol Cell Ther 1999;41(5):217-21.

[10] Platt OS, Thorington BD, Brambilla DJ, et al. Pain in sickle cell disease: rates and risk factors. N Engl J M 1991;325(1):11-6.

[11] Firkin FC, Chesterman C, Rush PB. Disorders of hemoglobin structure and synthesis. de Gruchy's clinical hematology in medical practice. Chapter 7. $5^{\text {th }}$ edn. Wiley Blackwell 1989:146.

[12] Al-Haggar M, Al-Marsafawy H, Abdel-Razek N, et al. Acute painful crisis of sickle cell disease in Egyptian children: predictors of severity for a preventive strategy. Int J Hematol 2006;83(3):224-8.

[13] Omoti CE. The value of fetal hemoglobin level in the management of Nigerian sickle cell anemia patients. Niger Postgrad Med J 2005;12(3):149-54.

[14] Gill FM, Sleeper LA, Weiner SJ, et al. Clinical events in the first decade in a cohort of infants with sickle cell disease. Cooperative Study of Sickle Cell Disease. Blood 1995;86(2):776-83.

[15] Stevens MC, Padwick M, Serjeant GR, et al. Observations on the natural history of dactylitis in homozygous sickle cell disease. Clin Pediatr (Phila) 1981;20(5):311-7.

[16] Powars DR, Chan L, Schroeder WA, et al. The influence of fetal hemoglobin on the clinical expression of sickle cell anemia. Ann N Y Acad Sci 1989;565:262-78.

[17] Subhedar BJ, Bhargawa HS. Sickle cell anemia in adolescents and adults. JAPI 1961;9:491.

[18] Ponnazhagan S, Sarkar R. Amelioration of clinical severity through raised fetal hemoglobin in sickle cell anemia. Indian J Pediatrics 1992;59(1):85-90.

[19] Watson J. A study of sickling of young erythrocytes in sickle cell anemia. Blood 1948;3(4):465-9.

[20] Stamatoyannopoulos G, Wood WG, Papayannopoulou $\mathrm{T}$, et al. A new form of hereditary persistence of fetal hemoglobin in blacks and its association with sickle cell trait. Blood 1975;46(5):683-92.

[21] Pollin WN, Kim BC, Castro 0, et al. Intracellular hemoglobin S polymerization and the clinical severity of sickle cell anemia. Blood 1998;91(5):1777-83. 